\title{
The Mechanism of Acute Renal Failure
}

\section{after Uranyl Nitrate}

\author{
Roland C. BLANTZ with the technical assistance of Karen Konnen \\ From the Departments of Medicine, University of California and Veterans \\ Administration Hospital, San Diego, California 92161
}

A в S T R A C T Administration of $25 \mathrm{mg} / \mathrm{kg}$ uranyl nitrate (UN) to rats leads to a brief period of polyuria followed by progressive oliguria with death at 5 days. Factors that determine glomerular filtration rate (GFR) were examined in control Munich-Wistar rats $(n=16)$ and $2 \mathrm{~h}$ after either $15 \mathrm{mg} / \mathrm{kg}(n=8)$ or $25 \mathrm{mg} / \mathrm{kg}$ $(n=7)$ of UN (i.v.) utilizing direct measurements of hydrostatic and oncotic pressures and plasma flow. Total kidney GFR was reduced to $47 \%$ of control in the low dose group and to $21 \%$ in the high dose group. The simultaneous nephron filtration rate (sngfr) was 28.6士 $0.8 \mathrm{nl} / \mathrm{min} / \mathrm{g}$ kidney wt in control, $29.1 \pm 1.0$ in the low dose group, and 18.1 $\pm 1.2(P<0.001)$ in the higher dose group. This disparity in UN effect upon GFR and sngfr was due to tubular back-diffusion of solute through damaged epithelia beyond the early proximal tubule as demonstrated by microinjection of inulin and mannitol in the proximal tubule. Inulin "leak" persisted at $6 \mathrm{~h}$ after UN when tubular pressure had returned to normal. Comparison of sngfr measured in early vs. late proximal tubule revealed no difference after high dose UN, suggesting no significant leak of inulin from the early proximal tubule, and that the decreased sngfr was due to primary reductions in ultrafiltration. Nephron plasma flow was equal to control at both doses of UN. Also directly measured hydrostatic pressure gradient across the glomerular capillary was not changed. The effective filtration pressure achieved equilibrium in control animals but became significantly positive at the efferent end of the capillary at both doses of UN and increased. Total glomerular permeability $\left(\mathrm{L}_{\mathrm{p}} \mathrm{A}\right)$ was progressively reduced from control $(0.089 \pm 0.005 \mathrm{nl} / \mathrm{s} / \mathrm{g}$ kidney $\mathrm{wt} / \mathrm{mm} \mathrm{Hg})$ at low

Portions of this work were presented at the Annual Meeting of The American Federation for Clinical Research, Atlantic City, N. J., 5 May 1974.

Received for publication 21 June 1974 and in revised form 18 November 1974. dose UN (0.047 \pm 0.013$)$ and high dose (0.024 \pm 0.003 $\mathrm{nl} / \mathrm{s} / \mathrm{g}$ kidney $\mathrm{wt} / \mathrm{mm} \mathrm{Hg}$ ). Therefore UN decreases GFR by two mechanisms: (a) tubular damage leading to back-diffusion of solutes and $(b)$ a primary reduction in sngfr due to reduced $L_{p} A$.

\section{INTRODUCTION}

A recent resurgence of interest in the pathogenesis of renal failure has focused attention upon the several factors which can potentially contribute to the reduction in glomerular filtration (GFR). ${ }^{1}$ Recent studies on this issue (1-6) have suggested the following mechanisms leading to a reduction in measured filtration rate: $(a)$ Renal vasoconstriction, which could decrease GFR by either a reduction in nephron plasma flow (rpf) or decrease the glomerular capillary hydrostatic pressure $\left(\mathrm{P}_{\mathrm{G}}\right) ;(b)$ tubular obstruction may lead to a reduction in filtration by elevating tubular pressure and reducing the hydrostatic pressure gradient acting across the glomerular capillary membrane $(\Delta \mathrm{P})(4-6)$; and $(c)$ transepithelial leak of solutes as large as inulin or lissamine

${ }^{1}$ Glossary of terms used in this paper: AR, afferent arteriolar resistance $C$, protein concentration; $C_{A}$, systemic protein concentration; $\mathrm{C}_{\mathrm{E}}$, efferent protein concentration; $\Delta \mathrm{P}$, hydrostatic pressure gradient between glomerular capillary and Bowman's space ( $\mathrm{mm} \mathrm{Hg})$; EFP, effective filtration pressure $(\mathrm{EFP}=\Delta \mathrm{P}-\pi)(\mathrm{mm} \mathrm{Hg}) ; \mathrm{FF}$, kidney filtration fraction (GFR/RPF); GFR, kidney filtration rate $(\mathrm{ml} / \mathrm{min} / \mathrm{g}$ kidney $\mathrm{wt}) ; \mathrm{L}_{\mathrm{p}} \mathrm{A}$, total glomerular permeability (nl/s/g kidney $\mathrm{wt} / \mathrm{mm} \mathrm{Hg}$ ); MAP, mean arterial blood pressure $(\mathrm{mm} \mathrm{Hg}) ; \mathrm{P}_{\mathrm{G}}$, glomerular capillary hydrostatic pressure $(\mathrm{mm} \mathrm{Hg}) ; \mathrm{P}_{\mathrm{t}}$, Bowman's space or proximal tubule hydrostatic pressure $(\mathrm{mm} \mathrm{Hg}) ; \pi$, oncotic pressure; rbf, nephron blood flow; rpf, nephron plasma flow (nl/ min/g kidney wt) ; RBF, kidney blood flow; RPF, kidney plasma flow $(\mathrm{ml} / \mathrm{min} / \mathrm{g}$ kidney $\mathrm{wt})$; snff, nephron filtration fraction (sngfr/rpf); sngfr, superficial nephron filtration rate (nl/min/g kidney wt); UN, uranyl nitrate; $x^{*}$, glomerular capillary length. 
TABLE I

Comparison of Clearance Values in Control Hydropenic, Low Dose (15 mg/kg) UN and High Dose (25 mg/kg) UN Groups

\begin{tabular}{|c|c|c|c|c|c|c|c|}
\hline Rat no. & sngfr & $\mathrm{rpf}$ & $\mathrm{C}_{\mathbf{A}}$ & $\operatorname{snff}(\mathrm{sngfr} / \mathrm{rpf})$ & GFR & $\mathrm{FF}$ (GFR/RPF) & $\dot{\mathrm{v}}$ \\
\hline & $\begin{array}{l}n l / \min / g \\
\text { kidney wt }\end{array}$ & $\begin{array}{l}n l / m i n / g \\
k i d n e y \text { wt }\end{array}$ & $\mathrm{g} / 100 \mathrm{ml}$ & & $\begin{array}{l}\mathrm{ml} / \mathrm{min} / \mathrm{g} \\
\text { kidney wt }\end{array}$ & & $\mu l / \min$ \\
\hline Control (16 rats) & $\begin{array}{c}28.6 \pm 0.8^{*} \\
(n=92)\end{array}$ & $\begin{array}{l}78.8 \pm 2.5 \\
(n=92)\end{array}$ & $\begin{array}{l}5.2 \pm 0.2 \\
(n=16)\end{array}$ & $\begin{array}{c}0.37 \pm 0.02 \\
(n=16)\end{array}$ & $\begin{array}{c}1.04 \pm 0.03 \\
(n=16)\end{array}$ & $\begin{array}{c}0.37 \pm 0.01 \\
(n=16)\end{array}$ & $\begin{array}{l}1.4 \pm 0.1 \\
(n=16)\end{array}$ \\
\hline \multicolumn{8}{|l|}{ UN $(15 \mathrm{mg} / \mathrm{kg})$} \\
\hline 3 & $32.3 \pm 1.0^{*}$ & $76.8 \pm 2.4$ & 3.7 & 0.42 & 0.90 & 0.39 & 3.0 \\
\hline 5 & $28.3 \pm 2.0$ & $128.8 \pm 9.2$ & 5.0 & 0.22 & 0.21 & 0.11 & 6.2 \\
\hline 7 & $30.8 \pm 3.0$ & $87.8 \pm 8.5$ & 5.7 & 0.35 & 0.82 & 0.14 & 2.8 \\
\hline 8 & $23.4 \pm 2.1$ & $48.4 \pm 4.4$ & 3.7 & 0.48 & 0.50 & 0.36 & 1.9 \\
\hline 11 & $35.3 \pm 3.1$ & $85.7 \pm 7.6$ & 4.5 & 0.41 & 0.28 & 0.03 & 5.8 \\
\hline 12 & $25.3 \pm 3.5$ & $85.0 \pm 11.8$ & 4.0 & 0.30 & 0.66 & 0.30 & 5.6 \\
\hline 13 & $24.6 \pm 2.1$ & $164.3 \pm 16.7$ & 4.8 & 0.16 & 0.18 & 0.09 & 3.1 \\
\hline 27 & $33.1 \pm 2.2$ & $114.1 \pm 7.6$ & 4.5 & 0.29 & 0.36 & 0.05 & 3.8 \\
\hline Overall mean & $\begin{array}{l}29.1 \pm 1.0^{*} \\
(n=46)\end{array}$ & $\begin{array}{c}93.5 \pm 5.9 \\
(n=46)\end{array}$ & $\begin{array}{l}4.5 \pm 0.2 \\
(n=8)\end{array}$ & $\begin{array}{c}0.33 \pm 0.04 \S \\
(n=8)\end{array}$ & $\begin{array}{c}0.49 \pm 0.10 \\
(n=8)\end{array}$ & $\begin{array}{c}0.18 \pm 0.05 \| \\
(n=8)\end{array}$ & $\begin{array}{l}4.0 \pm 0.6 \\
(n=8)\end{array}$ \\
\hline$P$ value & $>0.7$ & $<0.01$ & $<0.05$ & $>0.5$ & $<0.001$ & $<0.01$ & $<0.001$ \\
\hline \multicolumn{8}{|l|}{$\mathrm{UN}(25 \mathrm{mg} / \mathrm{kg})$} \\
\hline 15 & $20.0 \pm 0.7$ & $71.3 \pm 2.4$ & 4.7 & 0.28 & 0.06 & 0.04 & 4.9 \\
\hline 16 & $12.0 \pm 3.2$ & $57.2 \pm 15.1$ & 4.2 & 0.21 & 0.01 & 0.10 & 1.2 \\
\hline 18 & $17.2 \pm 2.3$ & $95.5 \pm 12.6$ & 4.3 & 0.18 & 0.05 & 0.00 & 2.7 \\
\hline 20 & $22.3 \pm 4.1$ & $61.9 \pm 11.4$ & 4.9 & 0.36 & 0.33 & 0.04 & 10.4 \\
\hline 21 & $23.6 \pm 1.7$ & $80.2 \pm 5.9$ & 4.4 & 0.30 & 0.30 & 0.00 & 4.8 \\
\hline 22 & $6.5 \pm 1.2$ & $34.4 \pm 6.6$ & 3.8 & 0.19 & 0.51 & 0.26 & 3.6 \\
\hline 23 & $21.6 \pm 1.1$ & $89.9 \pm 4.4$ & 4.8 & 0.24 & 0.30 & 0.04 & 9.6 \\
\hline Overall mean & $\begin{array}{l}18.1 \pm 1.2^{*} \\
(n=38)\end{array}$ & $\begin{array}{l}72.2 \pm 4.5 \\
(n=38)\end{array}$ & $\begin{array}{l}4.4 \pm 0.1 \\
(n=7)\end{array}$ & $\begin{array}{c}0.25 \pm 0.02 \S \\
(n=7)\end{array}$ & $\begin{array}{c}0.22 \pm 0.07 \\
(n=7)\end{array}$ & $\begin{array}{c}0.07 \pm 0.03 \| \\
(n=7)\end{array}$ & $5.3 \pm 1.3$ \\
\hline$P$ value $\ddagger$ & $<0.0001$ & $>0.1$ & $<0.02$ & $<0.005$ & $<0.0001$ & $<0.001$ & $<0.001$ \\
\hline
\end{tabular}

$*$ SEM.

$\ddagger$ Compared with control group.

$\$$ Determined by microprotein analysis of efferent peritubular samples.

$\| P<0.02$ when compared to snff in this group.

green, as a result of epithelial injury, requiring no primary alteration in filtration at the glomerulus (7-9).

The apparent disagreements which have arisen as to the exact mechanism for decreased GFR may have at least two explanations: (a) The experimental models which have been utilized differ rather markedly and $(b)$ the experimental observations have been obtained at widely varied time intervals after the initial injury (1-11).

The present study examines the mechanism of reduction of GFR very early after the administration of uranyl nitrate (UN) to determine the primary factors which initiate the process of this form of acute renal failure. We have chosen to examine early mechanisms causing a reduction in measured filtration because secondary effects of the agent, such as volume depletion, may complicate the interpretation of primary mechanisms. $\mathrm{UN}$ ( $\mathrm{UO}_{2}$ $\left(\mathrm{NO}_{8}\right)_{2}$ ) was utilized to induce acute renal failure because the pathology of this condition has been previously described in detail by Oliver (12) and involves the late proximal tubule, and in severe forms, the glomerulus. Prior data has revealed a high mortality in experi- 
mental animals after $15 / \mathrm{mg} / \mathrm{kg}$ or lesser doses of UN $(12,13)$. Also, with a given dose of this agent, the acute reduction in GFR was reasonably predictable and the involvement of superficial nephrons was also reasonably homogenous.

We have applied newer techniques of direct measurement of $P_{G}(14-16)$, microprotein analysis of the afferent and efferent oncotic pressures $(17,18)$, and microinjection methods to examine this issue and conclude that the reduction in measured GFR is a combination of (a) transepithelial leak of solutes across tubules and (b) a primary reduction in nephron filtration due to decreased total glomerular permeability $\left(\mathrm{L}_{\mathrm{p}} \mathrm{A}\right)$.

\section{METHODS}

Experiments were performed on male Munich-Wistar rats $(160-240 \mathrm{~g})$ which were anesthetized with inactin (100 $\mathrm{mg} / \mathrm{kg}$, i.p.), fed standard chow (Ralston Purina Co., St. Louis, Mo.), and permitted free access to water until the time of micropuncture. Studies were performed on three groups: control hydropenic rats $(n=16)$, a group after $15 \mathrm{mg} / \mathrm{kg} \mathrm{UN}$ (i.v., $n=8$ ), and a $25-\mathrm{mg} / \mathrm{kg} U N$ group $(n=7)$. Also, in a separate group of animals after $25 \mathrm{mg} /$ $\mathrm{kg}$ UN, microinjection studies were performed.

Surgical preparation for micropuncture was as previously described $(18,19)$. After placement of a tracheostomy and vascular catheters, a concentrated $\left(\mathrm{UO}_{2}\left(\mathrm{NO}_{3}\right)_{2}\right)$ solution in isotonic $\mathrm{NaCl}-\mathrm{NaHCO}_{3}$ was administered intravenously to deliver either 15 or $25 \mathrm{mg} / \mathrm{kg}$. Surgical losses were not replaced and this volume was small $(<0.2 \mathrm{ml})$. Usually a transient initial decrease in blood pressure was noted after the initial 2-5 $\mu 1$ of $\mathrm{UN}$, but blood pressure returned quickly to control levels and did not fall further with the remainder of the agent. Surgical preparation for micropuncture was then completed. $\left[{ }^{14} \mathrm{C}\right]$ Inulin was infused at $30-40 \mu \mathrm{Ci} / \mathrm{h}$ in a maintenance infusion of $\mathrm{NaCl}-\mathrm{NaHCO}_{z}$ $(0.5-0.6 \%$ body $\mathrm{wt} / \mathrm{h})$ in all groups. In all three groups (control, 15 and $25 \mathrm{mg} / \mathrm{kg} \mathrm{UN}$ ) nephron filtration rates (sngfr, $n=6$ ) and at least two clearance periods for total GFR were obtained. Data from 8 of the 16 control animals have appeared previously in a different form (17). Also samples of systemic blood and several samples of efferent peritubular blood were obtained. In addition, pressures were measured in surface glomerular capillaries, Bowman's space and tubules with a servo-nulling device. The methods utilized and the operation of the servo-nulling device have been described in a previous publication (14).

At the end of the last clearance period in each group, a renal vein sample was obtained by methods previously described to determine total filtration fraction from the extraction of radioactive inulin $(18,20)$.

sngfr in the proximal tubule. Because of the description of the UN pathology of involvement of the late proximal tubule and the pars rectal (12), sngfr were measured in the earlier proximal tubular segments. Tubular blockade was accomplished with oil blocks of at least three to four tubular diameters. Collections were made with care such that the tubular diameter proximal to the collection pipet remained constant during the collection, and that the oil block floated distally with ease with intermittent gentle counterpressure upon the syringe. These precautions were undertaken to assure that sngfr was not artifactually elevated since collections were made in the earlier proximal tubule, while tubular pressure was high (21).
To assess the possibility that inulin may leak from the earlier proximal tubular segments, a comparison of sngfr measured in earlier proximal to late proximal tubular loops was conducted. Comparison was not performed in the same nephron but in alternating early and late segments in the same animals.

Proximal tubular microinjection studies. Both $\left[{ }^{14} \mathrm{C}\right]-$ mannitol and $\left[\right.$ methoxy $\left.{ }^{3} \mathrm{H}\right]$ inulin were injected into early proximal tubular segments to determine the transepithelial leak of those substances in control, $25 \mathrm{mg} / \mathrm{kg}$ UN rats, after $2.5 \%$ (body wt) isoncotic plasma expansion (as a second control condition at high tubular pressure), and $6 \mathrm{~h}$ after $25 \mathrm{mg} / \mathrm{kg} \mathrm{UN}$. To isotonic $\mathrm{NaCl}-\mathrm{NaHCO}_{3}$ was added $\left[{ }^{14} \mathrm{C}\right]$ mannitol and $\left[{ }^{3} \mathrm{H}\right]$ inulin to a concentration of 0.40 and $0.69 \mu \mathrm{Ci} / \mu \mathrm{l}$, respectively and this fluid stained lightly with FD \& C green (Keystone Aniline \& Chemical Co., Chicago, Ill.). Samples of this fluid, made fresh each day, were obtained with a constant volume $4 \mathrm{nl}$, self-filling quartz pipet and placed under oil in the concavity of a special microscope slide. These samples were then aspirated under direct vision into $7-10-\mu \mathrm{m}$ tip pipets filled with mineral oil and tipped with a small quantity of the same oil. Alternate samples were delivered into liquid scintillation counting fluid and utilized as a $100 \%$ reference standard for total counts per minute of each isotope. Every other sample was utilized for microinjection into proximal tubular segments. The pipet was inserted carefully into an early proximal segment and a small amount of tubular fluid aspirated to clear the tip of the small quantity of oil. We have found that if even small amounts of mineral oil enter the tubule, either before or after the injection of the radioactive sample, recovery of radioactive marker from the left ureter in control animals is incomplete.

Since the radioactive sample was colored lightly with dye, this permitted visualization of the entire microinjection of material. In order for the injection to be considered adequate, dye must be retained entirely within the lumen and not leak around the pipet. The fluid was injected slowly over several minutes to maintain the tubular diameter constant and not to elevate the existing tubular pressure.

After initiation of the microinjection, urine samples were collected separately from the left and right ureters in 15min periods (usually two or three). 5-min urine collections were then obtained to determine that radioactive counts in the urine had returned to the background level before the next microinjection was begun.

Total ${ }^{14} \mathrm{C}$ and ${ }^{8} \mathrm{H}$ counts were separated based upon the relative count rates of ${ }^{14} \mathrm{C}$ and ${ }^{8} \mathrm{H}$ standards in ${ }^{14} \mathrm{C}$ and ${ }^{8} \mathrm{H}$ channels. Radioactivity from the left and right ureters were expressed as percentage of the mean of all $100 \%$ reference standards which alternated with injected samples.

Urinary volumes were higher than hydropenic controls (Table I) after UN and microinjections were performed at this spontaneous urine flow rate. Control microinjection studies differed from control hydropenic micropuncture studies in that urine flow was elevated by the infusion of $10 \%$ mannitol in $0.45 \% \mathrm{NaCl}-\mathrm{NaHCO}_{3}$ (i.v.) to raise urine volumes to three to four times the control urine flow rate, comparable to urine flow during UN studies. Microinjections conducted in rats after plasma expansion were performed at the resultant urine flow, usually only slightly higher than in UN rats. In separate studies, pressures, sngfr, and total kidney GFR were measured at approximately $6 \mathrm{~h}$ after $15 \mathrm{mg} / \mathrm{kg}$ UN administered subcutaneously. Rats were weighed at the time of injection and approximately $4 \mathrm{~h}$, at the the time of surgical preparation for micropuncture. Tubular microinjection studies were also 
performed at $6 \mathrm{~h}$ after $25 \mathrm{mg} / \mathrm{kg} \mathrm{UN}$ to determine tubular recovery of inulin and mannitol at this later time.

Calculations. sngfr is determined as follows:

$$
\text { sngfr }=\frac{\text { total urine } \mathrm{cpm} \text { of }{ }^{14} \mathrm{C}}{\text { plasma } \mathrm{cpm}{ }^{14} \mathrm{C} / \mathrm{nl} \cdot \text { time of collection }} .
$$

The nephron plasma flow (rpf) is calculated as follows:

$$
\mathrm{rpf}=\operatorname{sngfr} /\left(1-\mathrm{C}_{\mathbf{A}} / \mathrm{C}_{\mathrm{E}}\right),
$$

where $C_{A}=$ systemic protein concentration and $C_{E}=$ efferent peritubular capillary protein concentration determined by microprotein methods, and $\left(1-C_{A} / C_{E}\right)=$ the nephron filtration fraction (snff). The relationship between oncotic pressure $(\pi)$ and protein concentration (C) is defined by the following:

$$
\pi=1.76 \mathrm{C}+0.28 \mathrm{C}^{2} \text { (reference } 18 \text { ), }
$$

which is a least squares approximation of the original, empirical relationship noted by Landis and Pappenheimer (22) :

$$
\pi=2.1 \mathrm{C}=0.16 \mathrm{C}^{2}+0.009 \mathrm{C}^{3} .
$$

This relationship assumes that approximately $50 \%$ of total protein is albumin. We have performed protein electrophoresis upon the plasma of four rats after $25 \mathrm{mg} / \mathrm{kg}$ UN and the percentage albumin ranged from 46 to $55 \%$ fulfilling this criteria.

Afferent arteriolar resistance (AR) and nephron blood flow (rbf) are calculated as previously described (18).

Total GFR, renal plasma flow (RPF), renal blood flow $(\mathrm{RBF})$, and kidney filtration fraction (FF) were determined as previously described $(18,20)$.

The determinants of sngfr are defined as follows:

$$
\text { sngfr }=\mathrm{L}_{\mathrm{p}} \mathrm{A} \cdot \overline{\mathrm{EFP}},
$$

where $\mathrm{L}_{\mathrm{p}} \mathrm{A}=$ total glomerular permeability and $\overline{\mathrm{EFP}}=$ mean effective filtration pressure. The EFP along the glomerular capillary length $\left(x^{*}\right)$ is defined as follows:

$$
\operatorname{EFP}_{x^{*}}=(\Delta \mathrm{P}-\pi)_{x^{*}},
$$

and the $\overline{\mathrm{EFP}}$ by the following :

$$
\overline{\mathrm{EFP}}_{x^{*}}=\int_{0}^{1}(\Delta \mathrm{P}-\pi)_{x^{*}} \mathrm{~d} x^{*} .
$$

The sngfr relates to the rate of rpf along the $x^{*}$ as follows :

$$
\mathrm{rpf}_{\mathrm{o}}-\mathrm{rpf}_{1}=\mathrm{sngfr}=\mathrm{L}_{\mathrm{p}} \mathrm{A} \cdot \int_{0}^{1}(\Delta \mathrm{P}-\pi)_{x^{*}} \mathrm{~d} x^{*} .
$$

The profile of EFP along $x^{*}$ and a value for $\mathrm{L}_{\mathrm{p}} \mathrm{A}$ was determined from the measured data with a double iterative method as previously described (19), and by the integration method described by Deen, Robertson, and Brenner (23). The value for $L_{p} A$ and $\overline{E F P}$ after $U N$ were identical by both methods. $A$ unique value for $L_{p} A$ and $\overline{E F P}$ cannot be determined at filtration pressure equilibrium $\left(\pi_{\mathrm{E}} \cong \Delta \mathrm{P}\right)$, but rather only a maximum value for $\overline{\mathrm{EFP}}$ and a minimum value for $\mathrm{L}_{\mathrm{p}} \mathrm{A}$.

Analytical methods. Protein concentrations were determined in aortic and efferent peritubular capillary samples as described in a previous publication $(18,19)$. Urine and plasma electrolyte concentrations were determined on an Instrumentation Laboratory flame photometer (Instrumentation Laboratory, Inc., Lexington, Mass.) and osmolality with an Advanced Instruments osmometer (Advanced Instruments, Inc., Needham Heights, Mass.). Radioactivity was determined on a Packard liquid scintillation counter (model 2425, Packard Instrument Co. Inc., Downers Grove, I11.), and all samples were at least three times the background count rate.

Statistical methods. All input variables were analyzed by analysis of variance (24) and estimates of variance of all input parameters were carried through the calculation of EFP and $L_{p} A$ to determine a final estimate of variance in these values. In addition, the values determined for $L_{p} A$ in the two groups of UN rats were applied to the control hydropenic condition to determine if these values belong to the family of values of $\mathrm{L}_{\mathrm{p}} \mathrm{A}$ which fit the hydropenic control condition.

We have applied the Haldane-Cochran adaptation of the chi-squared test to determine the degree of relative homogeneity of both sngfr and tubular pressure within each animal in each experimental group (25). The absolute and weighted variances (as determined by the SD) were analyzed in each animal and compared with the control hydropenic condition as a further test of homogeneity of these parameters within each rat.

Electron microscopy. Electron microscopy was performed on a Siemens Elmskope 101 (Siemens Corp., Iselin, N. J.) at $80 \mathrm{kV}$ on $1-\mathrm{mm}^{3}$ sections of renal cortical tissue. The tissue was fixed immediately in $2 \%$ gluteraldehyde in phosphate buffer and remained in this solution for $3 \mathrm{~h}$, then postfixed with osmium tetroxide. The tissue was serially dehydrated in ethanol, infiltrated with propylene oxide, and mounted in Epon. Thin sections $(0.5-1.0 \mu \mathrm{m})$ were stained with UN and lead acetate and viewed under the electron microscope. 10 separate tissue sections were made for each hydropenic and high dose UN sample. Approximately 35 photographs were taken for each state to determine the morphologic changes in tubules and glomeruli.

\section{RESULTS}

After the intravenous UN there was transient decrease in urine volume, especially with the higher dose of this agent $(25 \mathrm{mg} / \mathrm{kg})$. After $20-30 \mathrm{~min}$ there was a consistent increase in urine volume above the preinjection level. The urine was occasionally blood tinged, but cleared by the time of measurements. Qualitative assessment of urine samples at the time of micropuncture measurements revealed no evidence of proteinuria. Urine volume from the left micropuncture kidney averaged $4.0 \pm 0.6 \mu \mathrm{l} / \mathrm{min}$ in the low dose group and $5.3 \pm$ $1.3 \mu \mathrm{l} / \mathrm{min}$ at the higher dose $2 \mathrm{~h}$ after administration of UN. This rate of urine flow was significantly higher than control hydropenic flow rates $(1.4 \pm 0.1 \mu \mathrm{l} / \mathrm{min})$.

Plasma sodium concentration was $136 \pm 3 \mathrm{meq} / \mathrm{liter}$, potassium $6.4 \pm 0.5 \mathrm{meq} /$ liter, and osmolality $296 \pm 5$ mosmol at the $15 \mathrm{mg} / \mathrm{kg}$ dose and $138 \pm 3 \mathrm{meq} / \mathrm{liter}$, $6.0 \pm 0.6 \mathrm{meq} / \mathrm{liter}$, and $283 \pm 15 \mathrm{mosmol}$, respectively at the higher dose, not different from the respective values in the control condition. Urines from micropuncture animals $2 \mathrm{~h}$ after UN were analyzed and re- 


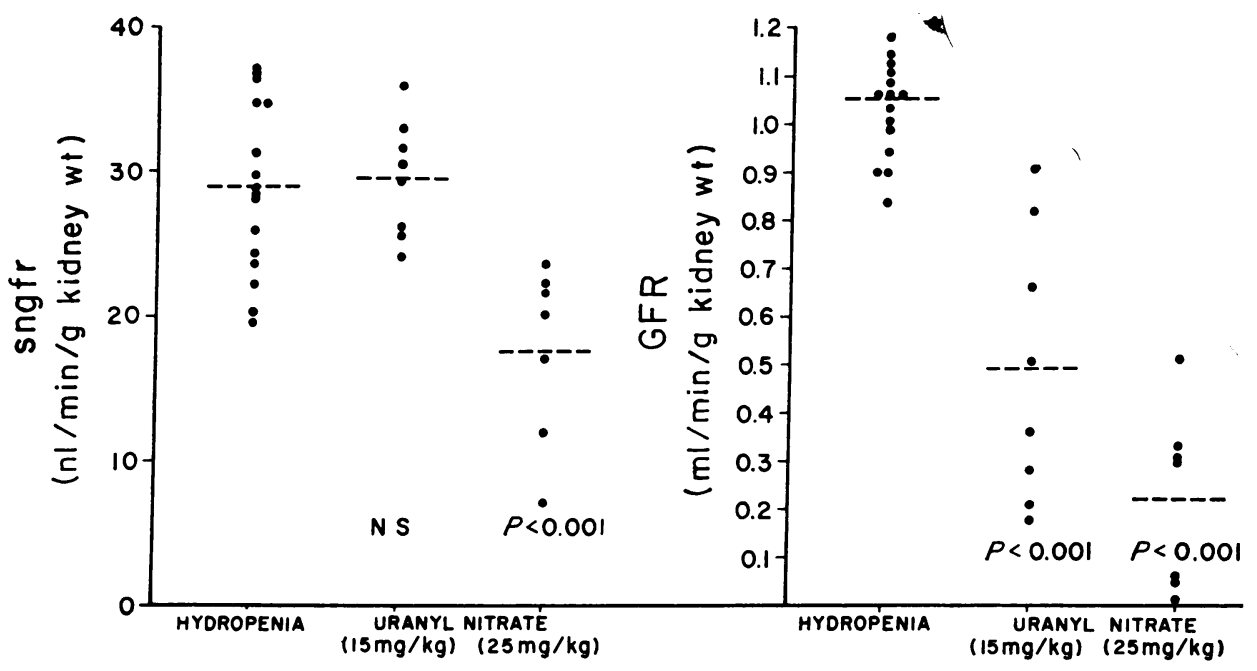

FIgURE 1 The effect of low (15 mg/kg) and high dose $(25 \mathrm{mg} / \mathrm{kg})$ UN upon sngfr and GFR. Each point represents the mean sngfr and GFR in each animal. At the lower UN dose, sngfr was equal to control hydropenic rats but was significantly lower at the high dose of UN. GFR, simultaneously determined with sngfr, fell to a greater extent than sngfr and was significantly lower than control in both 15 and $25 \mathrm{mg} / \mathrm{kg}$ UN groups.

vealed sodium and potassium concentrations of $140 \pm 9$ and $87 \pm 14 \mathrm{meq} / \mathrm{liter}$, respectively; values quite different from control hydropenic micropuncture animals. Sodium excretion averaged $0.80 \pm 0.12$ and potassium excretion $0.46 \pm 0.08 \mu \mathrm{eq} / \mathrm{min}$ during the micropuncture study. When expressed as the fractional excretion of sodium (clearance of sodium divided by the inulin clearance $\times 100)$, values averaged $8.2 \pm 1.5 \%$, considerably higher than the typically low values in hydropenic micropuncture rats (14).

Examination of the micropuncture surface of the kidney after UN revealed a homogeneous appearance of all tubules. The tubules were slightly but uniformly dilated but normal in color and appearance. No pigment or debri was noted in distal tubular segments. I stress this appearance to support our further contention that nephrons were uniformly involved within a given rat. There was no evidence of varying degrees of tubular obstruction and dilatation. We have observed the surface following the model of acute renal failure with glycerol induced myohemoglobinuria in this same species. In this model, marked heterogeneity of tubular color and radius occurs and pigment and debris are evident within distal tubules. This model of renal failure stands in marked contrast to the findings noted $2 \mathrm{~h}$ after UN.

Effect of $U N$ on sngfr and GFR. The resulting sngfr and GFR are demonstrated in Fig. 1 as the mean value in each animal. The sngfr after $15 \mathrm{mg} / \mathrm{kg}$ of UN $(n=46)$ was nearly identical to control animals $(n=$
92) at $29.1 \pm 1.0$ and $28.6 \pm 0.8 \mathrm{nl} / \mathrm{min} / \mathrm{g}$ kidney wt, respectively $(P>0.7)$. After $25 \mathrm{mg} / \mathrm{kg}$ of UN $(n=$ 38 ), the sngfr was significantly lower than either control or low dose UN groups $(18.1 \pm 1.2, P<0.001)$. When chi-squared tests were applied to data for sngfr within each animal, in only one of eight rats in the 15 $\mathrm{mg} / \mathrm{kg}$ UN group was sngfr more heterogeneous than in control animals. After $25 \mathrm{mg} / \mathrm{kg}$, four of seven rats had a more heterogeneous distribution of sngfr measured. To quantitate this degree of variance, we have analyzed each group with regard to the mean SD, expressed as a percentage of the mean value in each rat. In control the mean $\mathrm{SD}$ was $19 \pm 3 \%$ of the mean sngfr in each rat, $21 \pm 3 \%$ in $15 \mathrm{mg} / \mathrm{kg} \mathrm{UN}$ rats $(P>0.6)$, and $31 \pm 8 \%$ in the $25 \mathrm{mg} / \mathrm{kg}$ UN group $(P>0.1)$. Although there was a tendency for variance to be somewhat higher in the $25 \mathrm{mg} / \mathrm{kg}$ UN group, this did not achieve statistical significance.

The simultaneously determined GFR revealed that with either dose of UN, GFR was decreased to a greater extent than the corresponding sngfr (Fig. 1). Also, total FF was lower than the corresponding snff at either dose level of the nephrotoxic agent (Table I) $(P<0.02)$. This greater effect of UN upon GFR could have been the result of back-diffusion of radioactive inulin across damaged epithelia.

Microinjection studies. To determine if back-diffusion of solutes occurred after UN microinjection studies were performed. The results of microinjection of $\left[{ }^{8} \mathrm{H}\right]-$ inulin and $\left[{ }^{14} \mathrm{C}\right]$ mannitol into proximal tubules of con- 


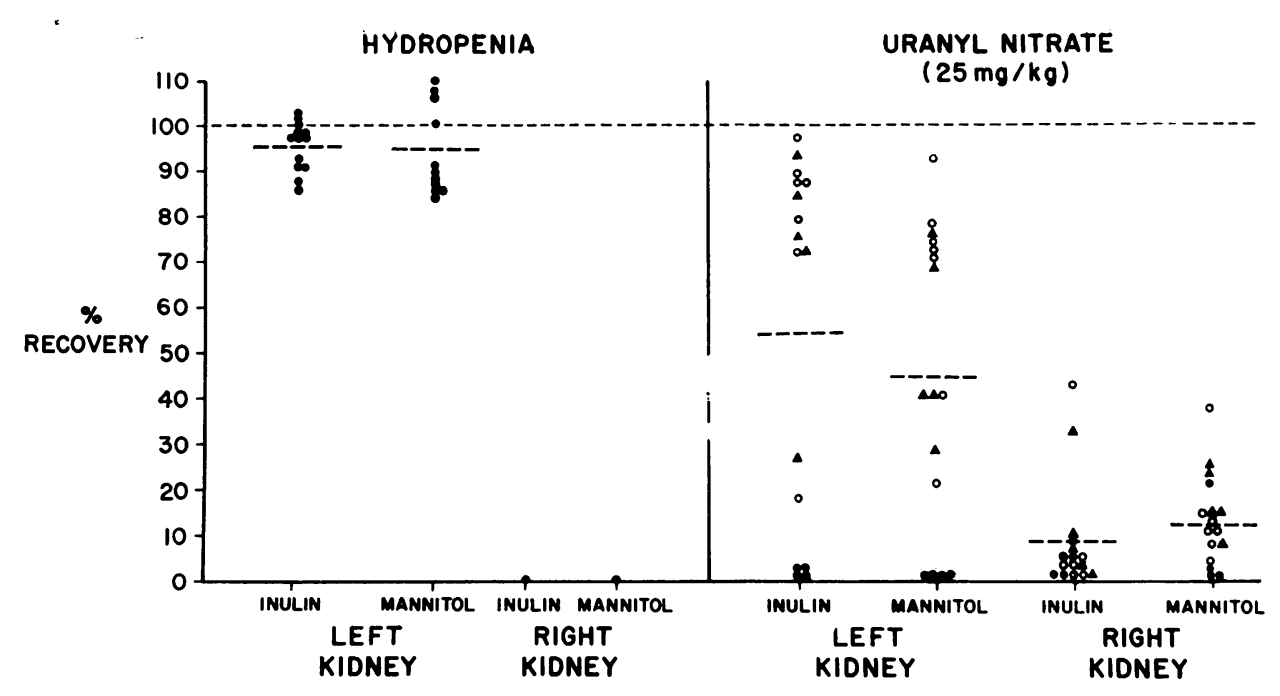

FIGURE 2 Recovery of proximal tubular microinjection of both $\left[{ }^{3} \mathrm{H}\right]$ inulin and $\left[{ }^{14} \mathrm{C}\right]$ mannitol from the left (microinjected) and right kidneys of control hydropenic rats (left) and in 25 $\mathrm{mg} / \mathrm{kg}$ UN rats (right). Recovery of inulin and mannitol from the microinjected left kidney was nearly complete at $96 \pm 1$ and $95 \pm 2 \%$, respectively, in control rats. However, in the 25 $\mathrm{mg} / \mathrm{kg}$ UN group, shown on the right, recovery of inulin and mannitol from the microinjected kidney was $55 \pm 10$ and $43 \pm 8 \%$. The different symbols in the UN group refer to the three different UN rats in which microinjections were performed. Within a given UN rat, recoveries were similar but varied among rats. Both inulin and mannitol were excreted from the right kidney due to significant tubular back-diffusion of these substances into the circulation. After UN, total recovery did not equal $100 \%$ due to loss of substances from the plasma because of the low GFR bilaterally. Microinjection studies at $6 \mathrm{~h}$ after UN revealed similar results with recoveries of $50 \pm 9$ and $44 \pm 8 \%$, respectively.

trol and $25 \mathrm{mg} / \mathrm{kg} \mathrm{UN}$ rats are shown in Fig. 2. Recovery of $\left[{ }^{3} \mathrm{H}\right]$ inulin from the urine of the left kidney of control rats averaged $96 \pm 1 \%$. $\left[{ }^{14} \mathrm{C}\right]$ Mannitol recovery from the left kidney of control rats was $95 \pm 2 \%$. There was no excretion of either radioactive inulin or mannitol from the right kidney in control animals. In rats after $25 \mathrm{mg} / \mathrm{kg} \mathrm{UN}$, there was a large variation in recovery of both radioactive markers from the urine of the left kidney $(n=16)$. The recoveries were significantly less than in the control hydropenic rats at $55 \pm 10$ and $43 \pm 8 \%$, respectively $(P<0.001)$. This variation in recovery was primarily the result of differences among animals, rather than variability among tubules within an animal. Points were derived from three rats and each rat is labeled with a specific symbol to dramatize this animal difference (Fig. 2). This variability in inulin recovery among animals is also noted in the $25 \mathrm{mg} / \mathrm{kg}$ UN rats in Table $\mathrm{I}$ where the ratio of reduced sngfr to GFR is quite different, primarily as the result of a larger variation in GFR reduction. Additional indirect evidence is provided by the variability in FF among rats after UN. Also, significant radioactive material was excreted from the right kidney at $7 \pm 3$ and $12 \pm 2 \%$, respectively. Total radioactivity excreted from both left and right kidneys was less than $100 \%$ after UN because of the very low GFR bilaterally, which permitted significant quantities of inulin and mannitol, which had leaked from the tubule, to leave the plasma volume. These results suggest that the greater reduction in total GFR with UN was the result of transepithelial back-diffusion of solutes of differing size such as inulin and mannitol.

To help define the reasons for this "leak" of inulin from tubules of UN rats, control microinjection studies of inulin and mannitol were also performed in rats after $2.5 \%$ (body wt) isoncotic plasma expansion. Both tubular pressure and rate of urine flow were similar to that found in UN rats. Recovery of inulin and mannitol was $92 \pm 3$ and $86 \pm 7 \%$, respectively $(n=8)$, not different from control animals $(P>0.6)$ and quite different from the low, abnormal recovery in UN rats. This finding demonstrates that elevation of tubular pressure and the mild diuretic state alone was not sufficient to explain the back-diffusion of inulin.

The question remained whether the significant reduction in sngfr noted with $25 \mathrm{mg} / \mathrm{kg}$ reflected a primary reduction in filtration at the glomerulus or leak of inulin from the early proximal tubule.

sngfr in the early and late proximal tubule. In order for back-leak of inulin to account for the observed $37 \%$ reduction in sngfr measured in the early proximal tubule, the leak must be of significant magnitude. We 
TABLE II

$\triangle P$ and $\pi$ in Control Hydropenic, Low Dose (15 mg/kg) UN and High Dose (25 mg/kg) UN Groups

\begin{tabular}{|c|c|c|c|c|c|}
\hline Rat no. & $P_{G}$ & $\Delta \mathrm{P}$ & $\pi_{\mathbf{A}}$ & $\pi \mathrm{E}$ & MAP \\
\hline & $m m \mathrm{Hg}$ & $m m \mathrm{Hg}$ & $m m \mathrm{Hg}$ & $m m \mathrm{Hg}$ & $m m \mathrm{Hg}$ \\
\hline Control (12 rats) & $\begin{array}{l}44.2 \pm 1.0^{*} \\
(n=32)\end{array}$ & $\begin{array}{c}30.8 \pm 1.0 \\
(n=32)\end{array}$ & $17.1 \pm 0.9$ & $33.8 \pm 1.4$ & $133 \pm 4$ \\
\hline \multicolumn{6}{|l|}{ UN $(15 \mathrm{mg} / \mathrm{kg})$} \\
\hline 5 & $\begin{array}{l}60.0 \pm 2.3 \\
(n=4)\end{array}$ & $\begin{array}{l}25.4 \pm 2.7 \\
(n=4)\end{array}$ & 15.9 & 23.0 & 123 \\
\hline 8 & $\begin{array}{l}58.9 \pm 4.0 \\
(n=4)\end{array}$ & $\begin{array}{l}34.1 \pm 4.0 \\
(n=4)\end{array}$ & 10.2 & 26.1 & 125 \\
\hline 12 & $\begin{array}{l}52.3 \pm 3.4 \\
(n=5)\end{array}$ & $\begin{array}{l}25.8 \pm 1.8 \\
(n=5)\end{array}$ & 11.4 & 19.0 & 115 \\
\hline 27 & $\begin{array}{c}54.4 \\
(n=1)\end{array}$ & $\begin{array}{c}21.5 \\
(n=1)\end{array}$ & 13.5 & 22.1 & 137 \\
\hline Overall mean & $\begin{array}{l}56.6 \pm 1.9^{*} \\
(n=14)\end{array}$ & $\begin{array}{c}27.7 \pm 1.8 \\
(n=14)\end{array}$ & $\begin{array}{c}12.8 \pm 1.2 \\
(n=4)\end{array}$ & $\begin{array}{c}22.5 \pm 1.5 \\
(n=4)\end{array}$ & $125 \pm 4$ \\
\hline$P$ value $\ddagger$ & $<0.001$ & $>0.1$ & $<0.05$ & $<0.001$ & $>0.5$ \\
\hline $\begin{array}{c}\mathrm{UN} \\
16\end{array}$ & $\begin{array}{l}51.8 \pm 1.2^{*} \\
(n=2)\end{array}$ & $\begin{array}{c}26.0 \pm 0.4 \\
(n=2)\end{array}$ & 12.3 & 17.2 & 122 \\
\hline 18 & $\begin{array}{l}63.6 \pm 3.1 \\
(n=2)\end{array}$ & $\begin{array}{l}28.4 \pm 0.8 \\
(n=2)\end{array}$ & 12.8 & 17.1 & 130 \\
\hline 20 & $\begin{array}{l}62.8 \pm 2.0 \\
(n=2)\end{array}$ & $\begin{array}{l}26.8 \pm 2.0 \\
(n=2)\end{array}$ & 15.2 & 29.8 & 130 \\
\hline 21 & $\begin{array}{c}64.3 \pm 2.4 \\
(n=6)\end{array}$ & $\begin{array}{c}31.0 \pm 3.4 \\
(n=6)\end{array}$ & 12.9 & 21.5 & 100 \\
\hline 22 & $\begin{array}{c}70.4 \\
(n=1)\end{array}$ & $\begin{array}{c}30.4 \\
(n=1)\end{array}$ & 10.5 & 14.4 & 86 \\
\hline 23 & $\begin{array}{l}53.9 \pm 3.7 \\
(n=2)\end{array}$ & $\begin{array}{l}35.4 \pm 7.0 \\
(n=2)\end{array}$ & 14.8 & 22.1 & 115 \\
\hline Overall mean & $\begin{array}{l}61.2 \pm 1.8^{*} \\
(n=15)\end{array}$ & $\begin{array}{c}30.0 \pm 1.7 \\
(n=15)\end{array}$ & $13.1 \pm 0.7$ & $20.4 \pm 2.2$ & $114 \pm 7$ \\
\hline$P$ value $\ddagger$ & $<0.001$ & $>0.6$ & $<0.02$ & $<0.001$ & $<0.01$ \\
\hline
\end{tabular}

$*$ SEM.

$\ddagger$ Compared to control group.

therefore compared sngfr measured in early proximal tubular segments to that obtained in late proximal segments to define the extent of leak in earlier segments. The sngfr in early proximal tubular segments in a separate group of $25 \mathrm{mg} / \mathrm{kg} \mathrm{UN}$ rats was $21.0 \pm 3.0 \mathrm{nl} / \mathrm{min} /$ kidney wt $(n=17)$ and $18.5 \pm 3.2$ in the latest accessible proximal tubular segments $(n=17) \quad(P>0.8)$. These data provide evidence against significant backdiffusion of inulin in the early proximal tubule. The measured sngfr in the early proximal tubule can therefore be interpreted as a valid indicator of the sngfr at the glomerulus. We will therefore proceed with analysis of the separate factors which can affect the sngfr.
Hemodynamic effects of $U N$. rpf was $93.5 \pm 5.9 \mathrm{nl} /$ $\mathrm{min} / \mathrm{g}$ kidney wt after $15 \mathrm{mg} / \mathrm{kg}$ of UN $(n=46)$ which was significantly different from the values in control rats $(78.8 \pm 2.5 \mathrm{nl} / \mathrm{min} / \mathrm{g}$ kidney wt, $n=92 P<0.01)$. In the $25 \mathrm{mg} / \mathrm{kg}$ UN group rpf was $72.2 \pm 4.5 \mathrm{nl} / \mathrm{min} / \mathrm{g}$ kidney wt $(n=38)$ which was not different from the control group $(P>0.1)$. rbf was unchanged after UN at both dose levels. Hematocrit was $54 \pm 1 \%$ in control, $50 \pm 1 \%$ at the lower UN dose $(P<0.05)$ and $47 \pm 1 \%$ $(P<0.01)$ at the higher UN dose level. This small fall in hematocrit must represent fluid entry into the vascular compartment since the rat was maintained at a hydropenic maintenance infusion rate during the 
TABLE III

Total $L_{p} A$ and $\overline{E F P}$ in Control Hydropenic, Low Dose (15 mg/kg) UN and High Dose (25 mg/kg) Groups

\begin{tabular}{lcc}
\hline & $\mathrm{L}_{\mathrm{pA}}$ & $\overline{\mathrm{EFP}}$ \\
\hline & $n l / s / \mathrm{g}$ kidney wt/mm $\mathrm{Hg}$ & $m m \mathrm{Hg}$ \\
Control & $0.089 \pm 0.005^{*} \ddagger$ & $5.1 \pm 1.2^{*} \S$ \\
$\mathrm{UN}(15 \mathrm{mg} / \mathrm{kg})$ & $0.047 \pm 0.013 \|$ & $10.2 \pm 1.8 \|$ \\
$\mathrm{UN}(25 \mathrm{mg} / \mathrm{kg})$ & $0.024 \pm 0.003 \|$ & $13.4 \pm 1.5 \|$ \\
\hline
\end{tabular}

$*$ SEM.

$\ddagger$ A minimum possible value at filtration pressure equilibrium. § A maximum possible value at filtration pressure equilibrium. $\|$ Significantly different from the control value (at least $P<0.05)$.

study. Mean arterial pressure (MAP) was $131 \pm 4 \mathrm{~mm}$ $\mathrm{Hg}$ in control rats, $119 \pm 5$ at the low dose $(P>0.05)$ and was significantly lower at the high dose of UN at $115 \pm 6 \mathrm{~mm} \mathrm{Hg}(P<0.025)$. Afferent arteriolar resistance was $0.53 \pm 0.04 \mathrm{nl} / \mathrm{min} / \mathrm{g}$ kidney $\mathrm{wt} / \mathrm{mm} \mathrm{Hg}$ in control rats and $0.37 \pm 0.05(P<0.05)$ and $0.38 \pm 0.06$ $\mathrm{nl} / \mathrm{min} / \mathrm{g}$ kidney wt $/ \mathrm{mm} \mathrm{Hg}(P>0.05)$ at the low and high dose, respectively. The reduction in sngfr after high dose UN was therefore not attributable to decreased rpf or vasoconstriction.

Total RPF was $2.9 \pm 0.2 \mathrm{ml} / \mathrm{min} / \mathrm{g}$ kidney wt in control animals, and not statistically different after low and high dose UN at $4.0 \pm 1.0$ and $4.0 \pm 1.7 \mathrm{ml} / \mathrm{min} / \mathrm{g}$ kidney wt $(P>0.5)$. The data on total RPF has a much greater error after UN because of the progressively small total FF with increasing dose of $\mathrm{UN}$, and the attendant inaccuracies in this determination. Total RBF in control was $6.3 \pm 0.4 \mathrm{ml} / \mathrm{min} / \mathrm{g}$ kidney wt in the con- trol group, $7.7 \pm 1.9$ at low dose $\mathrm{UN}$ and $7.8 \pm 3.4 \mathrm{ml}$ $\mathrm{min} / \mathrm{g}$ kidney wt at the higher UN dose $(P>0.5)$.

$C$ and $\pi$ after $U N . \mathrm{C}_{\triangle}, \mathrm{C}_{\mathrm{E}}$, and $\pi$ are demonstrated for all animals after $U N$ in Tables $I$ and II. $C_{\Delta}$ and $C_{x}$ were $5.2 \pm 0.2$ and $8.3 \pm 0.2 \mathrm{~g} / 100 \mathrm{ml}$ respectively $(n=$ 16). $C_{\Delta}$ and $C_{E}$ were both significantly decreased after both low and high dose UN. Also $\pi_{\Delta}$ and $\pi_{B}$ were significantly lower than control values in both groups.

Hydrostatic pressures after UN. Hydrostatic pressures were measured in glomerular capillaries and the corresponding Bowman's space $(\mathrm{Pt})$ in four rats in the low dose group and in six rats in the high dose UN group to describe fully the factors which determine the sngfr. $\Delta \mathrm{P}$ and $\pi$ in these animals as well as the values in control animals are demonstrated in Table II. Mean $P_{a}$ was $44.2 \pm 1.0 \mathrm{~mm} \mathrm{Hg}$ in control rats $(n=32)$, and significantly higher in the $15 \mathrm{mg} / \mathrm{kg} U N$ group $\left(\mathrm{P}_{\mathrm{a}}=56.6 \pm 1.9 \mathrm{~mm} \mathrm{Hg}, \boldsymbol{n}=14\right) \quad(P<0.001)$ and in the $25 \mathrm{mg} / \mathrm{kg}$ UN group $\left(\mathrm{Pa}_{\mathrm{a}}=61.2 \pm 1.8 \mathrm{~mm} \mathrm{Hg}, n=\right.$ 15) $(P<0.001)$. Tubular pressure was also significantly higher than control $\left(\mathrm{P}_{\mathrm{t}}=13.4 \pm 0.4 \mathrm{~mm} \mathrm{Hg}\right)$ in low $\left(\mathrm{P}_{\mathrm{t}}=28.8 \pm 1.5 \mathrm{~mm} \mathrm{Hg}(P<0.001)\right.$ and high dose UN groups $\left(P_{t}=31.3 \pm 2.1 \mathrm{~mm} \mathrm{Hg}\right)(P<0.001)$.

When statistical analyses of homogeneity of $\mathrm{P}_{\mathrm{t}}$ were conducted, as for sngfr, we find that in one of eight $15-\mathrm{mg} / \mathrm{kg}$ rats, $\mathrm{P}_{\mathrm{t}}$ observations among nephrons were more heterogeneous than control measurements and in six of seven rats in the $25 \mathrm{mg} / \mathrm{kg} U N$ group a more heterogeneous $\mathrm{P}_{\mathbf{t}}$ distribution was noted. When $\mathrm{SD}$ was expressed as a percentage of the observed mean, in control, the mean SD was $11 \pm 2 \%$ of the mean, $11 \pm 2 \%$ in the $15 \mathrm{mg} / \mathrm{kg} U N$ group $(P>0.8)$, and $23 \pm 3 \%$ in the $25 \mathrm{mg} / \mathrm{kg}$ UN group $(P<0.005)$. Although significantly different, the increase in variance for $P_{t}$ at the higher

TABLE IV

The Effect of UN $(25 \mathrm{mg} / \mathrm{kg})$ Administration on the Time Course of Urinary Sodium, Potassium, and Water Excretion before Death (day 5)

\begin{tabular}{lccccc}
\hline & & \multicolumn{4}{c}{ Days after UN } \\
\cline { 3 - 5 } & Control & 1 & 2 & 3 & 4 \\
\hline $\mathrm{V}, \mathrm{ml} / \mathrm{kg} / 24 \mathrm{~h}$ & $32.2 \pm 6.0^{*}$ & $113 \pm 7 \ddagger$ & $86 \pm 11$ & $41 \pm 12$ & $8.2 \pm 5.7 \S$ \\
$\mathrm{U}_{\mathrm{Na}}$, meq $/$ liter & $451 \pm 61$ & $204 \pm 17 \S$ & $83 \pm 13 \S$ & $56 \pm 9 \S$ & $50 \S$ \\
$\mathrm{U}_{\mathrm{K}, ~ m e q / l i t e r}$ & $205 \pm 22$ & $109 \pm 11 \S$ & $82 \pm 3 \S$ & $72 \pm 9 \S$ & $71 \S$ \\
$\mathrm{U}_{\text {osm }}$, mosmol & $1,931 \pm 263$ & $886 \pm 39 \S$ & $716 \pm 41 \S$ & $717 \pm 78 \S$ & $802 \pm 28$ \\
$\mathrm{U}_{\mathrm{Na}} \mathrm{V}, \mathrm{meq} / \mathrm{kg} / 24 h$ & $14.3 \pm 2.5$ & $23.5 \pm 3.4$ & $7.4 \pm 1.9$ & $2.3 \pm 0.7 \S$ & $1.2 \S$ \\
$\mathrm{U}_{\mathrm{K}} \mathrm{V}, \mathrm{meq} / \mathrm{kg} / 24 \mathrm{~h}$ & $6.5 \pm 1.1$ & $12.4 \pm 1.9 \ddagger$ & $7.1 \pm 0.9$ & $2.8 \pm 0.8 \S$ & $1.8 \S$ \\
\hline
\end{tabular}

$*$ SEM.

‡ Significantly higher than control (at least $P<0.05$ ).

$\$$ Significantly lower than control (at least $P<0.05$ ). 
UN dose was modest and is of the order observed in other experimental states with elevated tubular pressure (18). The data are not compatible with a markedly heterogeneous distribution of $\mathrm{P}_{t}$ which might be caused by tubular obstruction of a heterogeneous type.

The $\Delta \mathrm{P}$ was $30.8 \pm 1.0 \mathrm{~mm} \mathrm{Hg}$ in the control hydropenia group $(n=32)$. The $\Delta \mathrm{P}$ was $27.7 \pm 1.8 \mathrm{~mm} \mathrm{Hg}$ in the low dose UN group $(P>0.1)$ and $30.7 \pm 7$ in the high dose group $(P>0.6) .^{2}$

$E F P$ and $L_{p} A$. When the factors which determine glomerular ultrafiltration were analyzed in those animals in which direct measurements of $\Delta \mathrm{P}$ were obtained, significant differences from the control animals were noted. In control animals $(n=12)$ mean EFPA was $14.0 \pm 1.6 \mathrm{~mm} \mathrm{Hg}$ and $\mathrm{EFP}_{\mathrm{E}}-2.7 \pm 2.5 \mathrm{~mm} \mathrm{Hg}$. These values define a condition of filtration pressure equilibrium in which paired analysis of $\pi_{\mathrm{E}}$ and $\Delta \mathrm{P}$ for each animal revealed that these values were not different $(P>0.3)$.

In the lower dose UN group, sngfr was nearly identical to control while rpf was higher and $\pi_{\Delta}$ lower than control animals. The EFP profile along the length of the glomerular capillary $\left(x^{*}\right)$ also differed significantly from the control state. EFP $\mathrm{A}$ was $11.4 \pm 1.6 \mathrm{~mm} \mathrm{Hg}$ $(P>0.4)$, and the mean $\mathrm{EFP}_{\mathbf{x}}$ after low dose UN was $+4.2 \pm 2.0 \mathrm{~mm} \mathrm{Hg}(0.2>P>0.1) \quad(n=4)$. One of four animals however did achieve filtration pressure equilibrium (no. 27) and a second was only slightly positive $(+2.4)$. A minimum estimate of $L_{p} A$ could be determined for rat no. 27 , as was done in control animals at filtration equilibrium. $\mathrm{L}_{\mathrm{p}} \mathrm{A}$ in the low dose $\mathrm{UN}$ group was $0.047 \pm 0.013 \mathrm{nl} / \mathrm{s} / \mathrm{g}$ kidney $\mathrm{wt} / \mathrm{mm} \mathrm{Hg}$ compared to a minimum possible value of $0.089 \pm 0.005$ $\mathrm{nl} / \mathrm{s} / \mathrm{g}$ kidney $\mathrm{wt} / \mathrm{mm} \mathrm{Hg}(P<0.01)$ (Table III). When this value for $L_{p} A$ is applied to the hydropenic values for $\Delta \mathrm{P}$, rpf, and $\mathrm{C}_{\Delta}$, then the measured sngfr in these control animals $(30.0 \pm 0.7, n=12)$ cannot be achieved and a value of $22.2 \pm 2.4 \mathrm{nl} / \mathrm{min} / \mathrm{g}$ kidney $\mathrm{wt}$ results, which is significantly lower than the measured value $(P<0.02)$. This finding demonstrates that this value for $L_{p} A$ in the low dose group was lower than that family of values for $L_{p} A$ which permits the measured sngfr at filtration pressure equilibrium.

\footnotetext{
'Since there was potential for direct damage to the glomerular capillary as a result of the administration of UN, the accuracy of direct measurements could have been diminished. We have therefore examined estimates of $\mathrm{P}_{G}$ with the only other method available for calculation of $P_{G}$, the stop-flow technique (SFP). We have found that $\mathrm{P}_{a}$ and $P_{\text {SFr }}$ do not always correlate, especially in comparisons during hydropenia (13). Recognizing that identity does not prove validity, we found $P_{\text {SpP }}$ to be $52.1 \pm 1.6 \mathrm{~mm} \mathrm{Hg}$ ( $n=$ 24) in the low dose UN group and $57.1 \pm 2.3 \mathrm{~mm} \mathrm{Hg}$ in the high UN group $(n=23)$, values not statistically different from those obtained by direct $P_{G}$ measurements $(P>0.05$ and 0.10 , respectively).
}

$\overline{\mathrm{EFP}}$ was increased at $10.2 \pm 1.8 \mathrm{~mm} \mathrm{Hg}$ in the low dose UN group $(P<0.05)$, which was partially due to the increased plasma flow and reduced $\pi_{\Delta}$, but primarily the result of the reduction in $\mathrm{L}_{\mathrm{p}} \mathrm{A}$. The maximum possible value for $\overline{\mathrm{EFP}}$ in the control state was $5.1 \pm 1.2$ $\mathrm{mm} \mathrm{Hg}$. Since filtration pressure equilibrium obtains in the control hydropenic state, reciprocal elevations in $\overline{\mathrm{EFP}}$ will occur in response to the reduced $L_{p} \mathrm{~A}$ which will compensate at or near equilibrium and result in relative constancy of sngfr.

At the higher dose of UN, EFPA was $16.6 \pm 1.4 \mathrm{~mm}$ $\mathrm{Hg}(P>0.3)$. The EFP was higher than either control or low dose UN groups at $9.3 \pm 2.7 \mathrm{~mm} \mathrm{Hg}(P<$ $0.01)$. $\overline{\mathrm{EFP}}$ could be determined accurately and was significantly higher than control at $13.4 \pm 1.5 \mathrm{~mm} \mathrm{Hg}$. $(P<0.005)$. Since sngfr was significantly lower at this higher dose, $(18.1 \pm 1.2)$, it requires that $L_{p} A$ must have been further decreased at this higher dose of UN. $\mathrm{L}_{\mathrm{p}} \mathrm{A}$ was $0.024 \pm 0.003 \mathrm{nl} / \mathrm{s} / \mathrm{g}$ kidney $\mathrm{wt} / \mathrm{mm} \mathrm{Hg}$ and significantly lower than the minimum possible value in the control state $(P<0.001)$ (Table III). As in the low dose UN group, when this value for $L_{p} A$ was applied to the measured parameters in the control condition, an sngfr of only $15.2 \pm 1.8 \mathrm{nl} / \mathrm{min} / \mathrm{g}$ kidney $\mathrm{wt}$ was achieved. This value was much lower than the value measured, demonstrating again that this value was much lower than the control $\mathrm{L}_{\mathrm{p}} \mathrm{A}$.

The further reduction in $\mathrm{L}_{\mathrm{p}} \mathrm{A}$ with high dose $\mathrm{UN}$ has resulted in a significant decrease in sngfr, implying that $\mathrm{L}_{\mathrm{p}} \mathrm{A}$ must be reduced markedly from the value in hydropenia (at filtration pressure equilibrium) before an observable reduction in sngfr occurs. Under the conditions of the present study, a decrease in $\mathrm{L}_{\mathrm{p}} \mathrm{A}$ to $25-30 \%$ of the control value was required to produce a measurable decrease in sngfr.

Micropuncture studies $6 \mathrm{~h}$ after $U N$. At $6 \mathrm{~h}$ after $15 \mathrm{mg} / \mathrm{kg} \mathrm{UN}$, sngfr was $24.4 \pm 2.0 \mathrm{nl} / \mathrm{min} / \mathrm{g}$ kidney wt $(0.1>P>0.05$ compared to control rats) and GFR was $0.69 \pm 0.06(P<0.001)$. Tubular pressure at this time had returned to the normal hydropenic level at $13.1 \pm$ $0.4 \mathrm{~mm} \mathrm{Hg}(P>0.6$, compared to control hydropenic animals). Therefore filtration rates were similar to that observed at $2 \mathrm{~h}$ but tubular pressure had returned to normal. The rats were weighed at the time of injection and before surgery at $4 \mathrm{~h}$ and had lost $6.8 \pm 1.7 \mathrm{~g}$ during the interval. This was the consequence of an increase in urine flow which was not replaced by an increase in water intake. The reduction in tubular pressure was probably the result of this modest acute volume depletion.

Microinjection studies were also performed at $6 \mathrm{~h}$ after $25 \mathrm{mg} / \mathrm{kg}$ UN to determine if inulin back-diffusion was the result of tubular epithelial damage alone or also required an elevation in tubular pressure for full

Acute Renal Failure after Uranyl Nitrate 


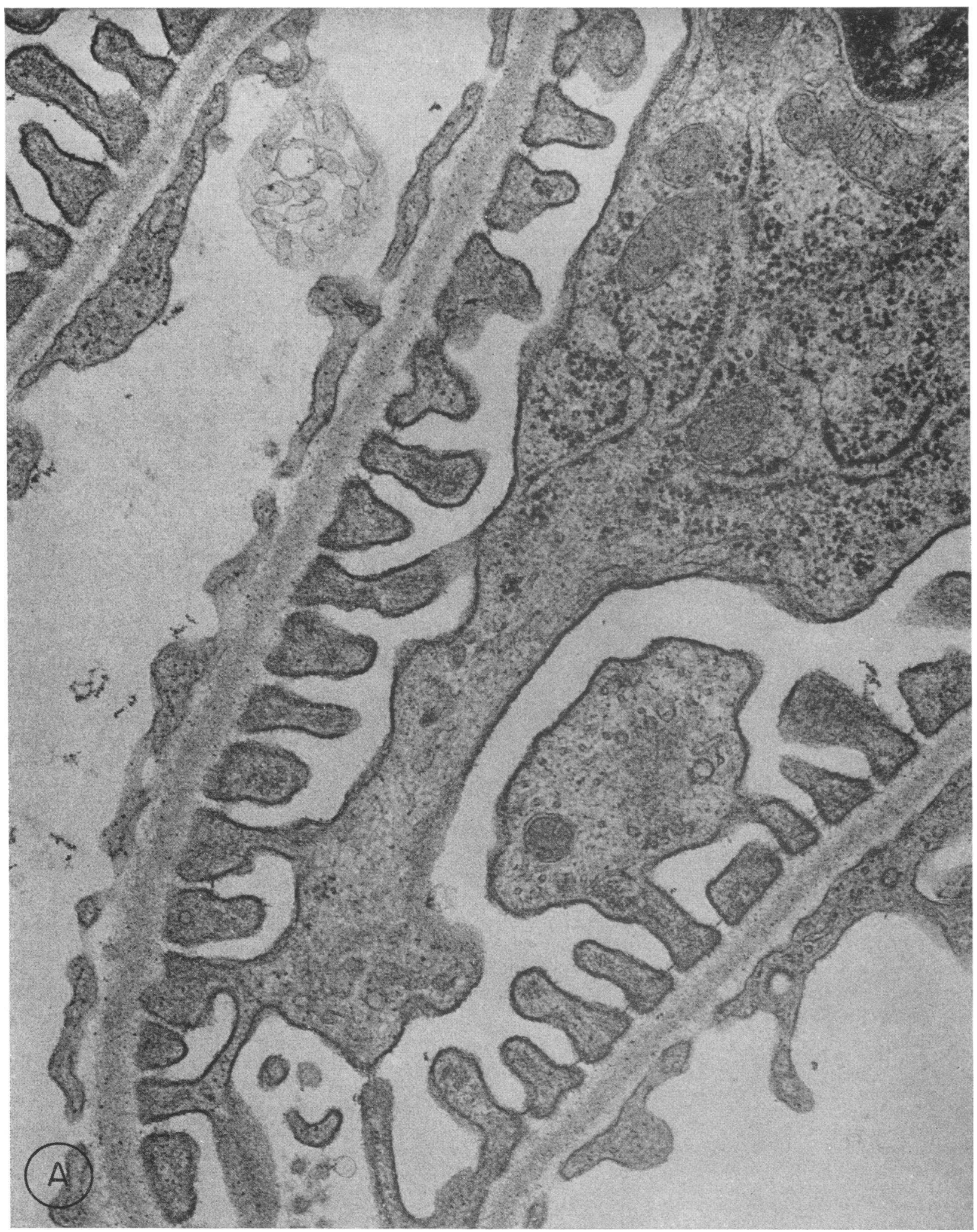

FIrURE 3 Representative electron micrographs of the glomerular basement membrane (A) $(\times 42,000)$ and a late proximal tubular cell $(B)(\times 21,000)$ are shown after $25 \mathrm{mg} / \mathrm{kg}$ UN. The glomerular basement membrane is entirely normal as are the filtration slits. However, the proximal tubular cell demonstrates two types of vacuoles, one of which contains membranous 


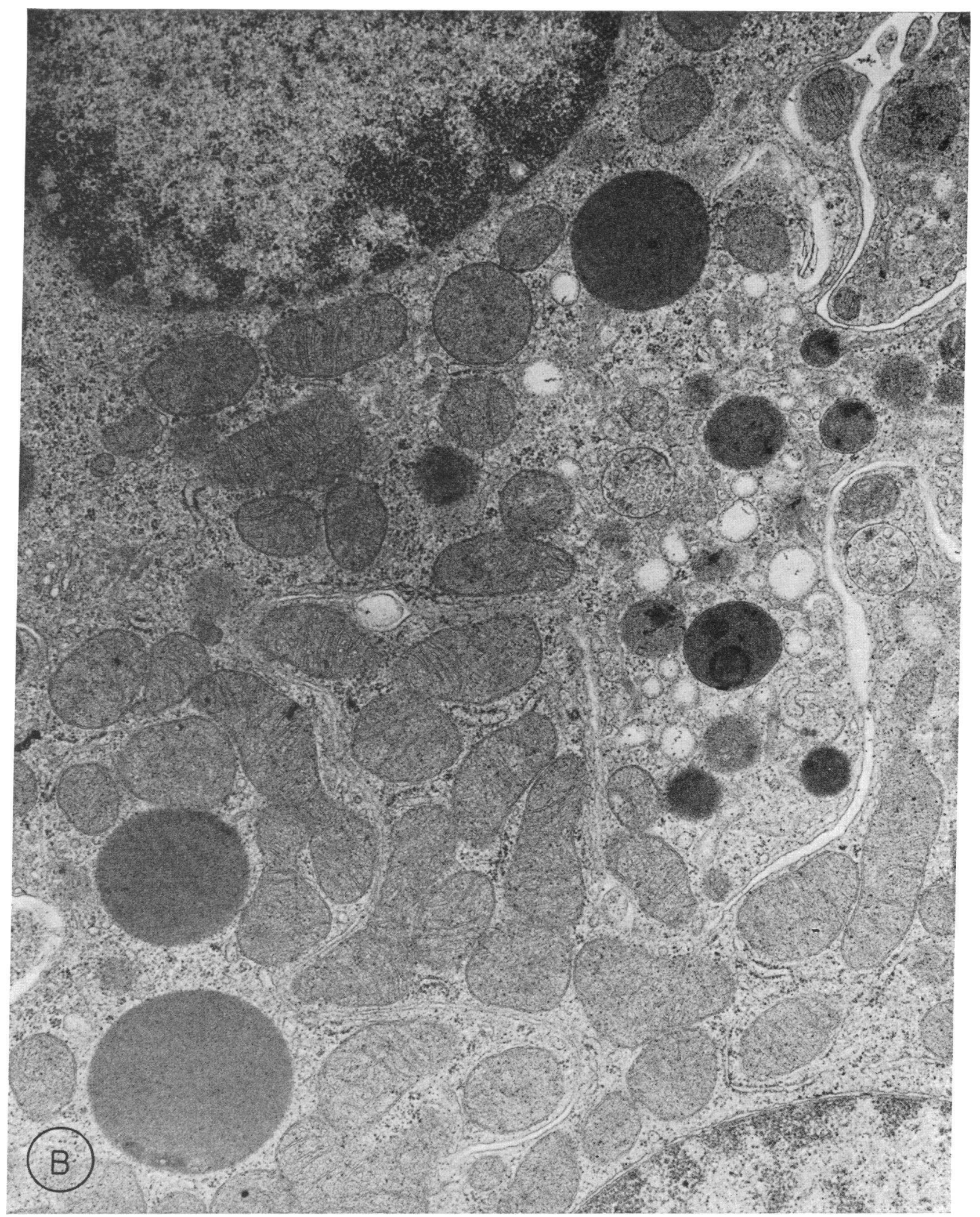

material, and mitochondrial abnormalities, with swelling and loss of normal cristae pattern. The intercellular channels were also widened when compared to control electron micrographs, but the tight junctures observed were entirely normal in configuration. Cortical distal tubular cells demonstrated similar, if more extensive, abnormalities after UN. 
expression. Inulin and mannitol recovery from the urine of the left, injected kidney was $50 \pm 9$ and $44 \pm 8 \%$, respectively, values significantly lower than both control hydropenic and plasma-expanded rats $(P<0.001)$ and nearly identical to microinjection studies at $2 \mathrm{~h}$. We conclude that inulin back-diffusion is the result of tubular damage primarily, and not the result of the initial elevation in $\mathrm{P}_{\mathrm{t}}$ observed at $2 \mathrm{~h}$ after $\mathrm{UN}$.

The course of renal failure after $U N$. We have focused primarily upon the factors which determine the early reduction in measured clearance after UN. Also, studies were conducted to examine the eventual course of UN nephrotoxicity. Four rats were injected with $25 \mathrm{mg} / \mathrm{kg} \mathrm{UN}$ and placed in metabolic cages and permitted free access to food and water. The pattern of excretion of water and electrolytes was examined and is demonstrated in Table IV. All rats died on the 5th day but appeared entirely normal until the 4th day when oliguria developed. The urine was protein free on the 1st day but proteinuria and low-grade glycosuria developed on the 2nd and 3rd day. Polyuria developed within the first $24 \mathrm{~h}$ and after the 1st day, there was a steady, uniform decline in urine volumes to the time of death. In the first 4 days the rats lost an average of $10.8 \pm 2.3 \mathrm{~g}$ in weight. In summary, UN produces a syndrome characterized by initial profound polyuria, secondary volume depletion, and eventual oliguria and death within 5 days. Progressive deterioration in renal function must occur and if correlated with prior histologic findings $(12,13)$, may be the result of progressive reductions in total glomerular permeability, continued increased tubular permeability and potential reductions in plasma flow secondary to volume depletion.

\section{Morphologic correlations}

Oliver in 1915 described specific changes by light microscopy after UN (12). The changes consisted of vacuolization of proximal tubules and mitochondrial changes which were most severe in the later portion of the proximal tubule, sparing to a great extent the early and midportions. Tissue was examined by Oliver from 6 to $96 \mathrm{~h}$ after the administered dose. We have reexamined renal tissue in control animals and after $25 \mathrm{mg} / \mathrm{kg}$ of UN. Since $\mathrm{L}_{\mathrm{p}} \mathrm{A}$ was reduced proportional to the dose administered, we have examined the glomerular structures in detail and have found no consistent abnormality in either the glomerular basement membrane or in slit pores (Fig. 3).

Proximal and distal tubular cells were also examined by electron microscopy. Vacuoles of two different types were noted in both proximal and cortical distal tubular cells. The first type of vacuole contained no defined structures and the second smaller vacuoles contained membranous structures, suggesting that they contained intracellular organelles (Fig. 3). Also the mitochondria demonstrated loss of cristae and were swollen in appearance. After UN the tight junctions that were observed were normal in appearance when compared to control sections, but the intercellular spaces were moderately widened as compared with control rats. The description of tubular abnormalities does not specifically explain the mechanism of transepithelial leak of inulin and mannitol. However, the morphologic alterations may be required to produce significant back-diffusion of solutes.

As further evidence of homogeneity of tubular damage with UN within a rat, electron micrographs revealed similar involvement of all late proximal and distal tubules. On the basis of data on sngfr, tubular pressures, electron micrographs, and the appearance of the kidney surface, tubular involvement was quite uniform and homogeneous within a UN rat. A heterogeneous type of tubular obstruction did not occur with $\mathrm{UN}$ and therefore did not contribute to either the reduction in inulin recovery or greater measured decrease in GFR after UN.

\section{DISCUSSION}

The recent development of newer micropuncture techniques has permitted the direct and quantitative evaluation of all the factors which determine the rate of nephron filtration. The development of the servo-nulling device and the discovery of the Munich-Wistar rat, a species with a high frequency of glomeruli on the kidney surface, permit direct assessment of the $\Delta \mathrm{P}(14-18,19)$. When these measurements are combined with microprotein analysis of afferent and efferent capillary blood samples and sngfr and the resulting data applied to mathematical models of glomerular ultrafiltration $(23,19)$, then a profile of the ultrafiltration pressure can be described and an estimation of total glomerular permeability can be obtained.

However, when these and other microtechniques are applied to animal models of clinical and pathologic conditions, it cannot be assumed that all measurements are equally valid as similar observations in the normal animal. The finding of a greater reduction in measured GFR than sngfr in the present study at both dose levels of UN is an example of such differences between the normal and the pathologic model. In a normal animal, this finding might be interpreted as evidence for "redistribution" of GFR or even complete cessation of filtration in deeper nephrons below the surface of the kidney. Another alternative is that sngfr was overestimated in both UN groups by providing a lower resistance pathway into the collection pipet and lowering the elevated tubular pressure. Because of this potential artifact, we carefully did not alter tubular diameter proximal to the pipet and per- 
mitted the oil block to float a short distance from the pipet. Andreucci, Herrera-Acosta, Rector, and Seldin have examined this issue at high tubular pressures and found it impossible to significantly elevate sngfr, even with maximum aspiration pressures (21). In addition, data from this study demonstrate that snff were consistently higher than FF, which agrees with the finding of a greater reduction in kidney inulin clearance. In order for the sngfr to be lower than the measured values, and equal to the GFR reduction, errors of $100 \%$ in sngfr would be required, a highly unlikely phenomenon. The major conclusions of this study would not be changed, but $L_{p} A$ would be further reduced.

If the epithelium has become permeable to inulin, inulin clearance as an index of kidney GFR is no longer valid. In the present study, we have found such an increase in inulin permeability which could account for approximately one-half of the observed decrease in measured GFR after UN administration in the higher dose group and $100 \%$ of the reduction observed at the lower dose. At the higher dose the observed $37 \%$ reduction in sngfr combined with a minimum estimate of $45 \%$ back diffusion of inulin to give a predicted total GFR of 0.35 $\mathrm{ml} / \mathrm{min} / \mathrm{g}$ kidney wt, a value only slightly higher than the observed value of $0.22 \mathrm{ml} / \mathrm{min} / \mathrm{g}$ kidney wt.

The finding of inulin back-diffusion adequately explains the greater reduction in kidney inulin clearance observed $2 \mathrm{~h}$ after UN. The acute elevation in tubular pressure was not the cause of this increased inulin permeability because $(a)$ elevations in tubular pressure and similar levels of natriuresis after isoncotic plasma expansion were not associated with inulin back-diffusion and $(b)$ rats studied $6 \mathrm{~h}$ after $25 \mathrm{mg} / \mathrm{kg}$ of UN continued to demonstrate increased tubular permeability to inulin, in spite of the fact that tubular pressures had returned to normal values, similar to control hydropenic rats. Therefore increased tubular permeability to inulin is primarily the result of epithelial damage after UN. Lorentz, Lassiter, and Gottschalk have demonstrated that elevation of tubular pressure through ureteral obstruction, saline expansion, and renal venous occlusion in the normal rat does not result in increased tubular permeability to inulin. Smaller molecules such as mannitol, sucrose, and creatinine were noted to back-diffuse from the tubular lumen at elevated tubular pressures in normal rats (26).

We have provided several lines of evidence for a relatively uniform tubular involvement as a result of UN nephrotoxicity. The appearance of the kidney, histologic changes, and data on tubular pressures and sngfr suggest that heterogeneous tubular obstruction was not a characteristic of this form of nephrotoxic renal failure. The reduction in inulin recovery and resulting greater decrease in measured GFR was therefore not the result of a "spotty" form of tubular obstruction but increased tubular "leak." In recent studies that have also reported a reduced inulin recovery after microinjection studies in ischemic forms of renal failure $(8,9)$, it is not possible to conclude whether such a heterogeneous tubular obtruction occurred, or if true increased tubular permeability was the sole reason for these findings.

The marked early elevation in tubular pressure after UN is likely the result of the effect of the agent on tubular cells and sodium transport. Fractional and absolute sodium reabsorption was reduced and sodium and water excretion increased acutely. The tubular pressures observed are admittedly much higher than is usually associated with this modest diuresis. However, if tubular obstruction was present in the studies at $2 \mathrm{~h}$ after UN, it must represent a highly uniform tubular involvement, a finding unlikely to result from epithelial debris within the more distal tubules. After the early onset of polyuria, tubular pressures had returned to normal values at $6 \mathrm{~h}$. A consistent volume depletion was observed and undoubtedly was an important factor in the reduction in tubular pressure.

Studies comparing early to late proximal tubular sngfr measurements suggest that leak from the early proximal tubule is minimal, in that values could not be differentiated in high dose UN rats. These findings suggest that the $37 \%$ reduction in sngfr observed in collections from the early proximal tubule at the higher dose represents a true decrease in filtration at the glomerulus. The location of tubular leak of inulin then correlates well with the initial pathologic findings described by Oliver (12). There was some evidence for a greater variability among rats of the tubular leak of inulin than in the primary reduction in sngfr (Table I). This heterogeneity of tubular effects among rats is reflected in the variation in the ratio of sngfr to GFR after high dose UN. Electron micrographs did not reveal the exact mechanism for the transtubular leak, although distinctive abnormalities were noted (Fig. 3).

The second reason for the decrease in measured kidney GFR involves a true reduction in nephron filtration as a result of a marked decrease in $\mathrm{L}_{\mathrm{p}} \mathrm{A}$. In spite of evidence presented suggesting that significant leak of inulin did not occur from the early proximal tubule, it remains possible that sngfr was underestimated for other technical reasons. However, even if this were possible, calculated $\mathrm{L}_{\mathrm{p}} \mathrm{A}$ would continue reduced due to the finding of disequilibration of the EFP. In order for $\mathrm{L}_{\mathrm{p}} \mathrm{A}$ to be in error and actually equal to control values, would require two independent errors; and underestimation of sngfr and an underestimation of $\pi_{\mathrm{E}}$ from microprotein determinations, and to the proper degree, an unlikely possibility.

Acute Renal Failure after Uranyl Nitrate 
Direct evidence for a reduction in $L_{p} A$ in acute renal failure has not previously been reported. Cox et al. have suggested such a mechanism in an ischemic model of renal failure (11). Also, in a recent report, Bennett and co-workers have shown a reduction in $L_{p} A$ while sngfr was unchanged in the early phase of acute experimental glomerulonephritis (27). The decreased $\mathrm{L}_{\mathrm{p}} \mathrm{A}$ after $\mathrm{UN}$ could be either the result of a decrease in the filtering surface area of the glomerulus (A) or a true decrement in hydraulic permeability $\left(L_{P}\right)$.

At the lower dose of $\mathrm{UN}$, sngfr was maintained in spite of a marked reduction in $L_{p} A$, due to a large increase in $\overline{\mathrm{EFP}}$. This increase was partially the result of decreased $\pi_{\Delta}$ and a small increase in rpf, but primarily the result of the decreased $L_{p} A$. With a lower value for $\mathrm{L}_{\mathrm{p}} \mathrm{A}$, the rate of ultrafiltration at any point along the glomerular capillary length $\left(x^{*}\right)$ will be decreased and the rate of rise in $\pi$ will be reduced. The net effect will be an increase in $\overline{\mathrm{EFP}}$, which at filtration pressure equilibrium, will compensate for significant $\mathrm{L}_{\mathrm{p}} \mathrm{A}$ reductions and maintain sngfr. With further disequilibration of $\mathrm{EFP}_{\mathbb{E}}$ the increasing $\overline{\mathrm{EFP}}$ will not remain directly inversely proportional to the reduction in $\mathrm{L}_{\mathrm{p}} \mathrm{A}$ and sngfr will fall, as noted in the $25 \mathrm{mg} / \mathrm{kg}$ UN group. A reduction in the $\Delta \mathrm{P}$ per se does not either disequilibrate the EFP or reduce $L_{p} A$. In isoncotic plasma-expanded rats, a condition in which $L_{p} A$ can be calculated with accuracy because of disequilibration of EFP, increased ureteral pressure resulted in tubular pressures similar to those after $\mathrm{UN}$, and no reduction in $\mathrm{L}_{\mathrm{p}} \mathrm{A}$ was observed (unpublished observations). However, we have noted a modest disequilibration of EFP after ureteral obstruction in hydropenic rats which must be a result of a reduction in the calculated glomerular permeability coefficient. This apparent difference in response to ureteral obstruction between groups may be due to the state of volume expansion and the capacity to release factors such as angiotensin.

The fall in $\pi_{\Delta}$ with UN may have resulted from loss of protein from the plasma volume or as a result of fluid entering the plasma volume. However, we did not observe significant proteinuria at $2 \mathrm{~h}$ after the agent.

Contrary to previous reports in the dog (10), we could not demonstrate that RPF was reduced $2 \mathrm{~h}$ after the administration of UN. rpf was increased at the lower dose and equal to control after high dose UN. Also, $\mathrm{P}_{\mathrm{G}}$ was not reduced, but elevated significantly above the control value. Afferent resistance was therefore not increased acutely at either dose of UN. After UN injection, animals died uniformly at 5 days, soon after the onset of frank oliguria, probably as the result of either uremia or hyperkalemia. The progression of acute renal failure was the result of both a primary reduction in glomerular permeability and continued tubular back- diffusion of solutes as large as inulin. Further compromise in renal function may have also resulted from the polyuria and volume depletion through secondary reductions in renal plasma flow. Reduction in RPF secondary to vasoconstriction was not an early primary cause for the decrease in measured filtration rate.

The question remains as to the applicability of the present findings of increased tubular permeability to large solutes and reduced total glomerular permeability to other clinical forms of acute renal failure. It seems likely that forms of acute renal failure characterized by definite tubular injury may also be associated with an increased tubular permeability to molecules as large as inulin. Increased back-diffusion of solutes, normally retained within the tubular lumen, will also contribute to acute renal failure and to the uremic state. A specific role for decreased total glomerular permeability cannot be assigned to other forms of acute renal failure with certainty. However, we have demonstrated in this study that $L_{p} A$ is significantly reduced before the onset of definite electron micrographic changes in the glomerulus. Since definite histologic abnormalities of the glomerulus become more evident at a later time after UN $(12,13)$, further reductions may have occurred with time and contributed to further reductions in sngfr.

\section{ACKNOWLEDGMENTS}

Our appreciation is extended for the excellent secretarial support provided by Ms. Barbara Drysdale. We are grateful to Fred S. Wright, Department of Physiology, Yale University for his helpful advice with tubular microinjection studies. Electron micrographs were performed by Dr. Peter J. Kiessling, Department of Pathology, University of California, San Diego, Calif.

Studies were supported through grants from the National Institutes of Health (HL-14914) and from the Veterans Administration. Work was performed during the author's tenure as a Research and Education Associate of the Veterans Administration.

\section{REFERENCES}

1. Thiel, G., D. R. Wilson, M. L. Arce, and D. E. Oken. 1967. Glycerol induced hemoglobinuric acute renal failure in the rat. II. The experimental model, predisposing factors, and pathophysiologic features. Nephron. 4: 276296.

2. Flanigan, W. J., and D. E. Oken. 1965. Renal micropuncture study of the development of anuria in the rat with mercury induced acute renal failure. J. Clin. Invest. 44: 449-457.

3. Oken, D. E., M. L. Arce, and D. R. Wilson. 1966. Glycerol-induced hemoglobinuric acute renal failure in the rat. I. Micropuncture study of the development of oliguria. J. Clin. Invest. 45: 724-735.

4. Jaenicke, J. B. 1969. Micropuncture study of methemoglobin-induced acute renal failure in the rat. J. Lab. Clin. Med. 73: 459-468.

5. Ayer, G., A. Grandchamp, J. Wyler, and B. Truniger. 1971. Intrarenal hemodynamics in glycerol-induced myohemoglobinuric acute renal failure in the rat. Circ. Res. 29: 128-135. 
6. Henry, L. N., C. E. Lane, and M. Kashgarian. 1968. Micropuncture studies of the pathophysiology of acute renal failure in the rat. Lab. Invest. 19: 309-314.

7. Bank, N., B. F. Mutz, and H. S. Aynedjian. 1967. The role of "leakage" of tubular fluid in anuria due to mercury poisoning. $J$. Clin. Invest. 46: 695-704.

8. Eisenbach, G. M., and M. Steinhausen. 1973. Micropuncture studies after temporary ischemia of rat kidneys. Pfluegers Arch. Eur. J. Physiol. 343: 11-25.

9. Tanner, G. A., K. L. Sloan, and S. Sophasan. 1973. Effects of renal artery occlusion on kidney function in the rat. Kidney Int. $4:$ 377-389.

10. Flamenbaum, W., J. S. McNeil, T. A. Kotchen, and A. J. Saladino. 1972. Experimental acute renal failure induced by uranyl nitrate in the dog. Circ. Res. 31: 682-698.

11. Cox, J. W., R. W. Baehler, H. Sharma, T. O'Dorisio, R. W. Osgood, and J. H. Ferris. 1974. Studies on the mechanism of oliguria in a model of unilateral renal failure. J. Clin. Invest. 53 : 1546-1558.

12. Oliver, J. 1915. The histogenesis of chronic uranium nephritis with especial reference to epithelial regeneration. J. Exp. Med. 21: $425-451+8$ plates.

13. Bencosme, S. A., R. S. Stone, H. Laha, and S. E. Madden. 1960. Acute tubular and glomerular lesions in rat kidneys after uranium injury. Arch. Pathol. 69: 122128.

14. Blantz, R. C., A. H. Israelit, F. C. Rector Jr., and D. W. Seldin. 1972. Relation of distal tubular $\mathrm{NaCl}$ delivery and glomerular hydrostatic pressure. Kidney Int. 2: 22-32.

15. Brenner, B. M., J. L. Troy, and T. M. Daugharty. 1971. The dynamics of glomerular ultrafiltration in the rat. J. Clin. Invest. 50: 1776-1780.

16. Brenner, B. M., J. L. Troy, T. M. Daugharty, W. M. Deen, and C. R. Robertson. 1972. Dynamics of glomerular ultrafiltration in the rat. II. Plasma flow dependence of G.F.R. Am. J. Physiol. 223: 1184-1190.
17. Brenner, B. M., K. H. Falchuk, R. I. Keimowitz, and R. W. Berliner. 1969. The relationship between peritubular capillary protein concentration and fluid reabsorption by the renal proximal tubule. J. Clin. Invest. 48: 1519-1531.

18. Blantz, R. C., F. C. Rector, Jr., and D. W. Seldin. 1974. Effect of hyperoncotic albumin expansion upon glomerular ultrafiltration in the rat. Kidney Int. 6: 212223.

19. Blantz, R. C. 1974. Effect of mannitol on glomerular ultrafiltration in the hydropenic rat. J. Clin. Invest. 54: $1135-1143$

20. Wallin, J. D., R. C. Blantz, M. A. Katz, V. E. Andreucci, F. C. Rector Jr., and D. W. Seldin. 1971. Effect of saline diuresis on intrarenal blood flow in the rat. Am. J. Physiol. 221: 1297-1304.

21. Andreucci, V. E., J. Herrera-Acosta, F. C. Rector Jr., and D. W. Seldin. 1971. Measurement of single-nephron glomerular filtration rate by micropuncture: analysis of error. Am. J. Physiol. 221: 1551-1559.

22. Landis, E. M., and J. R. Pappenheimer. 1963. Exchange of substances through the capillary walls. Handb. Physiol. 2(Sect. 2) : 961-1034.

23. Deen, W. M., C. R. Robertson, and B. M. Brenner. 1972. A model of glomerular ultrafiltration in the rat. Am. J. Physiol. 223: 1178-1183.

24. Snedecor, G. R. 1956. Statistical Methods. Iowa State University Press, Ames, Iowa.

25. Cochran, W. G. 1954. Some methods for strengthening the $\chi^{2}$ tests. Biometrics. $10: 417-451$.

26. Lorentz, W. B., Jr., W. E. Lassiter, and C. W. Gottschalk. 1972. Renal tubular permeability during increased intrarenal pressure. J. Clin. Invest. 51: 484-492.

27. Bennett, C. M., D. A. Maddox, T. M. Daugharty, R. J. Glassock, T. Kwong, D. Knutson, W. M. Deen, C. R. Robertson, and B. M. Brenner. 1974. Determinants of glomerular filtration in experimental glomerulonephritis. J. Clin. Invest. 53: 5a-6a. (Abstr.) 